\title{
STUDY EXPLORATION THEMATIC LEARNINGBASED ON LOCAL WISDOM OF CENTRAL JAVA ON FOURTH GRADE OF ELEMENTARY SCHOOL
}

\section{Priskila Dwinando Marindasari, Sri Marmoah, Sri Yamtinah}

Universitas Sebelas Maret

priskiladidi@gmail.com

\section{Article History}

accepted 09/07/2018

approved 01/08/2018

published 17/09/2018

Keywords

Exploration study, Local wisdom, Thematic Learning, Elementary School

\begin{abstract}
This study aims to obtain a description of knowledge about thematic learning based on local wisdom of Central Java in fourth grade elementary school students. The type of this research is descriptive research. The study was conducted through field studies to obtain a picture of the knowledge of teachers and learners about thematic learning based on local wisdom of Central Java in fourth grade elementary school students. The results showed that in general the teacher of fourth grade of elementary school in Surakarta had not fully taught local wisdom of Central Java in thematic learning. Teachers are more focused on teaching the material on student books. Some teachers expect training to design and create learning that is capable of developing cognitive, affective, and psychomotor abilities and can introduce local wisdom of Central Java for learners. While learners expect an interesting source of learning and able to make them learn independently. At the same time can recognize local wisdom in the area
\end{abstract}

Social, Humanities, and Education Studies (SHEs): Conference Series https://jurnal.uns.ac.id/shes

p-ISSN 2620-9284 e-ISSN 2620-9292 


\section{PENDAHULUAN}

Permendikbud no. 56 tahun 2014 mengatur tentang kurikulum pendidikan di Indonesia, bahwa pelaksanaan kurikulum 2013 pada Sekolah Dasar/ Madrasah Ibtidaiyah dilakukan melalui pembelajaran dengan pendekatan tematik terpadu dari kelas I sampai VI. Pembelajaran tematik ini mengadopsi model webbed (jaring labalaba) dari Fogarty. Fogarty (2009: 65) mengatakan bahwa "webbed curricula represent the thematic approach to integrating subject matter. Typically, this thematic approach to curriculum development begins with a theme such as transportation or inventions". Kurikulum jaring laba-laba mewakili pendekatan tematik untuk mengintegrasikan materi pelajaran. Biasanya, pendekatan tematik ini untuk pengembangan kurikulum dimulai dengan tema seperti transportasi atau penemuan. Tema ini menjadi alat pemersatu materi yang beragam dari beberapa mata pelajaran. Nurlaela (2018) mengatakan bahwa "In the thematic learning presenting the lessons based on themes that connect the various related subjects might provide different learning outcomes for each student with different learning styles". Dalam pembelajaran tematik menyajikan pelajaran berdasarkan tema yang menghubungkan berbagai mata pelajaranterkait yang mungkin memberikan hasil pembelajaran yang berbeda untuk setiap peserta didik dengan gaya belajar yang berbeda. Dengan demikian, pembelajaran tematik adalah pembelajaran yang mengintegrasikan berbagai kompetensi dari berbagai mata pelajaran ke dalam suatu tema pembelajaran.

Dalam permendikbud no 56 tahun 2014, peserta didik adalah pewaris budaya bangsa yang kreatif. Proses pendidikan haruslah memberikan kesempatan kepada peserta didik untuk mengembangkan potensi dirinya dengan memberikan makna yang ditentukan oleh lensa budayanya dan sesuai dengan kematangan psikologis dan fisik peserta didik. Menurut Utari (2016), pembelajaran tematik yang meaningful dan joyful dapat diwujudkan dengan mengaitkan materi pembelajaran dengan dunia terdekat peserta didik melalui penanaman nilai-nilai kearifan lokal dimana peserta didik berada. la mendefinisikan kearifan lokal sebagai kecendikiaan terhadap kekayaan setempat/ suatu daerah berupa pengetahuan, kepercayaan, norma, adat istiadat, kebudayaan, wawasan dan sebagainya yang merupakan warisan dan dipertahankan sebagai identitas dan pedoman dalam kehidupan. Sementara Tinja (2017) mengatakan bahwa kearifan lokal merupakan kebiasaan-kebiasaan yang tertanam kuat dalam kehidupan masyarakat tertentu yang mengandung unsur nilai budaya yang tinggi. Mungmachon (2012) mengatakan bahwa "Local wisdom is basic knowledge gained from living in balance with nature. It is related to culture in the community which is accumulated and passed on." Kearifan lokal adalah pengetahuan dasar yang diperoleh dari hidup seimbang dengan alam. Ini terkait dengan budaya dikomunitas yang terakumulasi dan diwariskan. Dengan demikian kearifan lokal adalah kebiasaan-kebiasaan yang merupakan warisan budaya suatu daerah sebagai identitas dan pedoman dalam kehidupan.

Berdasarkan hasil observasi proses pembelajaran tematik di SD negeri di Kota Surakarta menunjukkan bahwa proses pembelajaran tematik di kelas sudah berjalan cukup baik. Guru berusaha melakukan komunikasi dua arah dengan peserta didik dengan cara memberikan pertanyaan yang harus dijawab peserta didik, menanggapi peserta didik yang mengajukan pertanyaan, dan memberikan motivasi kepada peserta didik agar aktif dalam proses pembelajaran. Namun, guru lebih sering menggunakan model pembelajaran langsung karena dinilai lebih efektif dan efisien. Untuk menunjang proses pembelajaran, guru menggunakan buku ajar dari pemerintah, meskipun buku ajar tersebut berkonteks nasional. Guru juga menggunakan buku pendamping dari penerbit tertentu yang tidak jauh beda dari buku yang diterbitkan pemerintah.

Berdasarkan hasil wawancara terhadap guru dan peserta didik, diperoleh informasi bahwa materi yang ada pada buku dari pemerintah maupun dari penerbit masih kurang lengkap, kurang mendalam, dan belum sesuai dengan kearifan lokal 
dimana peserta didik berada, yaitu kearifan lokal Jawa Tengah. Namun guru belum pernah mengembangkan bahan ajar sendiri karena merasa kesulitan menyatukan materi dalam pembelajaran tematik. Guru juga kesulitan mendesain bahan ajar agar lebih menarik karena keterbatasan ilmu computer yang dimiliki guru.

Realita di lapangan, sebagian besar guru menggunakan bahan ajar yang telah disediakan pemerintah, yang mana buku tersebut berkonteks nasional. Buku pendamping yang digunakan guru berasal dari penerbit tertentu yang mungkin tidak sesuai dengan kearifan daerah dimana peserta didik tersebut berada. Kondisi yang demikian dapat mempersulit peserta didik dalam mengenal kearifan lokal yang ada di daerahnya masing-masing. Bahan ajar cetak yang biasa digunakan guru dan peserta didik dalam pembelajaran tematik kurang mengedepankan unsur kearifan lokal

Terkait dengan permasalahan di atas maka diperlukan adanya pengembangan bahan ajar yang tidak hanya berkonteks nasional namun juga berkonteks daerah sehingga peserta didik dapat lebih mengenal kearifan lokal yang ada di daerahnya. Opera dan Oguzor (2011: 66) menyatakan bahwa "instructional materials are the audio visual materials (software/ hardware) which can be used as alternative channels of communication in the teaching-learning process". Bahan ajar merupakan sumber belajar berupa visual maupun audiovisual yang dapat digunakan sebagai saluran alternatif pada komunikasi di dalam proses pembelajaran. Gogoi (2015) mengatakan bahwa "teaching materials can improve students 'learning motivation and make it easier for teachers to develop students' cognitive abilities, so that learning is more meaningful for them". Bahan ajar dapat meningkatkan motivasi belajar peserta didik dan memudahkan guru untuk mengembangkan kemampuan kognitif peserta didik, sehingga pembelajaran lebih bermakna bagi mereka.

Pengembangan bahan ajar yang dipilih adalah bahan ajar berbasis kearifan lokal yang berpijak pada teori kontekstual. Bahan ajar yang akan dikembangkan dibuat semenarik mungkin dengan menampilkan ilustrasi yang memuat unsur-unsur kearifan lokal Jawa Tengah. Materi yang disajikan juga akan berhubungan dengan unsur-unsur kearifan lokal Jawa Tengah sehingga nantinya melalui pembelajaran tematik dapat menambah pengetahuan peserta didik mengenai kearifan lokal Jawa Tengah dengan lebih baik.

Berdasarkan uraian di atas, maka permasalahan yang ada di lapangan adalah bagaimana pembelajaran tematik berbasis kearifan lokal pada peserta didik kelas IV Sekolah Dasar? Adapun pertanyaan penelitian yang diuraikan adalah (1) bagaimana kondisi lapangan terkait pemahaman guru dan pelaksanaan proses pembelajaran tematik berbasis kearifan lokal pada peserta didik kelas IV Sekolah Dasar? (2) bagaimana penerapan dan implementasi sumber belajar sebagai acuan dalam pembelajaran tematik berbasis kearifan lokal pada peserta didik kelas IV Sekolah Dasar?

Penelitian ini bertujuan untuk memperoleh gambaran pengetahuan tentang pembelajaran tematik berbasis kearifan lokal Jawa Tengah pada peserta didik kelas IV sekolah dasar. Berdasarkan tujuan umum tersebut kemudian dijabarkan lagi ke dalam tujuan khusus, meliputi: (1) mengetahui kondisi lapangan terkait pemahaman guru dan pelaksanaan proses pembelajaran tematik berbasis kearifan lokal pada peserta didik kelas IV Sekolah Dasar, (2) mendeskripsikan penerapan dan implementasi sumber belajar sebagai acuan dalam pembelajaran tematik berbasis kearifan lokal pada peserta didik kelas IV Sekolah Dasar.

\section{METODE}

Jenis penelitian yang digunakan adalah penelitian deskripsi. Kegiatan awal yang dilakukan adalah survey lapangan. Survey ini bertujuan untuk mengumpulkan informasi dari guru dan peserta didik terkait dengan bahan ajar tematik yang digunakan 
di sekolah dasar. Selain itu juga untuk memperoleh informasi tentang pemahaman guru terhadap pembelajaran tematik berbasis kearifan lokal Jawa Tengah sekaligus penerapannya dalam proses pembelajaran di dalam kelas. Hasil yang diperoleh melalui kegiatan survey lapangan ini akan dijadikan pertimbangan dalam penyusunan bahan ajar yang tepat, sehingga pada tahap selanjutnya, peneliti dapat menyusun draf bahan ajar.Studi eksplorasi dilakukan untuk memperoleh informasi yang mendalam mengenai: (1) kondisi nyata mengenai pembelajaran tematik berbasis kearifan lokal Jawa Tengah di wilayah Kota Surakarta, (2) kondisi nyata tentang kebutuhan guru dan peserta didik sekolah dasar kelas IV dalam pemanfaatan sumber belajar dan bahan ajar dalam pembelajaran tematik berbasis kearifan lokal Jawa Tengah. Subjek penelitian ini adalah peserta didik dan guru kelas IV sekolah dasar di Kota Surakarta, Jawa Tengah. Sekolah dasar yang digunakan dalam penelitian ini adalah sekolah dasar di wilayah Kota Surakarta yang ditentukan dengan teknik cluster random sampling. Teknik pengumpulan data melalui wawancara guru dan peserta didik, observasi kegiatan pembelajaran, dan catatan lapangan berupa RPP. Teknik validasi data dengan triangulasi sumber dan metode. Analisis data menggunakan model analisis interaktif deskriptif.

\section{HASIL DAN PEMBAHASAN}

Hasil analisis kurikulum 2013 menunjukkan bahwa terdapat sembilan tema yang harus diajarkan di kelas IV sekolah dasar. Tema 1 sampai 5 diajarkan pada semester ganjil, sedangkan tema 6 sampai 9 diajarkan pada semester genap. Tema-tema tersebut dapat dilihat pada tabel 1 berikut.

Tabel 1. Tema-tema Kelas IV Sekolah Dasar Kurikulum 2013
\begin{tabular}{|c|l|}
\hline Tema ke & \multicolumn{1}{c|}{ Judul Tema } \\
\hline 1 & Indahnya Kebersamaan \\
\hline 2 & Selalu Berhemat Energi \\
\hline 3 & Peduli terhadap Makhluk Hidup \\
\hline 4 & Berbagai Pekerjaan \\
\hline 5 & Pahlawanku \\
\hline 6 & Indahnya Negeriku \\
\hline 7 & Cita-Citaku \\
\hline 8 & Tempat Tinggalku \\
\hline 9 & Makananku Sehat dan Bergizi \\
\hline
\end{tabular}

Pada masing-masing tema mengandung kompetensi dasar yang dijabarkan dalam tujuan pembelajaran kognitif, afektif, dan psikomotorik yang harus dikuasai peserta didik. Setiap tema tersebut disusun dalam suatu buku pegangan bagi guru dan siswa yang dapat digunakan selama proses pembelajaran.

Berdasarkan hasil studi eksplorasi yang dilakukan di lapangan dalam pembelajaran tematik, diperoleh hasil sebagai berikut. 1) Semua guru menggunakan buku guru dan buku siswa yang diperoleh dari pemerintah. 2) Sebagian besar guru menggunakan buku pegangan tertentu yang dibeli dari penerbit, namun belum ada guru yang menggunakan buku pegangan pembelajaran tematik lain yang berbasis kearifan lokal Jawa Tengah. 3) Pembelajaran yang dilakukan guru dalam pembelaran 
tematik sering menggunakan model pembelajaran langsung karena dinilai lebih efektif dan efisien. 4) Materi yang disajikan dalam buku ajar tematik masih bersifat umum berskala nasional dan belum menunjukkan spesifikasi materi sesuai dengan kearifan lokal yang ada di masing-masing daerah.

Northcote (2014) mengatakan bahwa integrasi nilai budaya lokal dalam pengembangan kurikulum seperti membuat tujuan belajar, merancang bahan belajar, menentukan strategi pembelajaran, media belajar, dan evaluasi pembelajaran adalah penting dilakukan untuk kualitas pembelajaran. Hal ini karena kearifan local memiliki berbagai fungsi. Fungsi tersebut diantaranya: (1) sebagai penanda identitas sebuah komunitas, (2) sebagai elemen perekat lintas warga, agama, dan kepercayaan, (3) memberikan warna kebersamaan bagi sebuah komunitas, (4) mengubah pola pikir dan timbal balik individu dan kelompok dengan meletakkannya di atas kebudayaan yang dimiliki, dan (5) mendorong terbangunnya kebersamaan, apresiasi sekaligus sebagai mekanisme bersama untuk menepis berbagai kemungkinan yang meredusir, bahkan merusak solidaritas komunal, yang dipercaya berasal dan tumbuh di atas kesadaran bersama (Sumarmi dan Amirudin, 2014). Agar fungsi tersebut dapat tertanam dalam diri peserta didik, maka nilai budaya local perlu diintegrasikan dalam bahan belajar. Prastowo (2012: 17) berpendapat bahwa bahan ajar pada dasarnya merupakan segala bahan (baik informasi, alat, maupun teks) yang disusun secara sistematis, yang menampilkan sosok utuh dari kompetensi yang akan dikuasai peserta didik dan digunakan dalam proses pembelajaran dengan tujuan perencanaan dan penelaahan implementasi pembelajaran. Sedangkan Nasution(2010: 12) mengatakan bahwa bahan ajar merupakan sumber belajar yang secara sengaja dikembangkan untuk tujuan pembelajaran.Dengan demikianbahan ajar adalah seperangkat materi pelajaran yang mengacu pada kurikulum yang disusun secara sistematis, yang menampilkan sosok utuh dari kompetensi yang akan dikuasai peserta didik dan penelaahan implementasi pembelajaran guna mencapai standar kompetensi dan kompetensi dasar yang ditentukan. Guru di sekolah dasar membutuhkan bahan ajar yang mengajarkan adanya unsur-unsur kearifan lokal sehingga memudahkan guru untuk mengenalkan kearifan lokal khususnya Jawa Tengah kepada peserta didik. Adanya pengetahuan tentang unsur-unsur kearifan lokal tersebut diharapkan dapat menjadikan peserta didik memahami kearifan lokal dan lebih mencintai daerah tempat tinggalnya. Bahan ajar yang dimaksud harus berisikan materi yang jelas sesuai dengan kurikulum yang berlaku dan dapat memudahkan peserta didik untuk memahami materi dengan jelas melalui belajar mandiri, juga mampu menarik kemauan peserta didik dalam mengikuti pembelajaran tematik.

Berdasarkan analisis kebutuhan peserta didik dapat diketahui bahwa sebagian peserta didik merasa kesulitan dalam melakukan kegiatan pembelajaran tematik dikarenakan contoh dan pengalaman yang ada pada buku pegangan siswa tidak ditemukan dalam kehidupan sehari-hari yang ada di daerahnya. Hasil evaluasi peserta didik dalam beberapa subtema belum menunjukkan hasil yang memuaskan. Nilai yang diperoleh peserta didik rata-rata kurang dari angka 7 dari angka maksimal 10 . Pengetahuan peserta didik mengenai kearifan lokal yang ada di daerahnya pun juga minim. Misalnya, banyak peserta didik yang tidak mengenal arti sebenarnya dari acara sekaten. Hasil wawancara terhadap beberapa peserta didik menunjukkan bahwa sebagian besar dari mereka mengatakan sekaten merupakan acara yang berlangsung selama setahun sekali. Acara sekaten merupakan kegiatan pasar malam. Banyak orang berjualan ketika malam hari dan banyak juga permainan-permainan yang disiapkan bagi pengunjung. Peserta didik kurang memahami bahwa acara sekaten merupakan tradisi memperingati maulid Nabi Muhammad SAW.Padahal mereka merupakan anak-anak asli kota Surakarta, dimana acara sekaten diadakan setiap tahun. 
Berdasarkan hasil tahap studi eksplorasi, maka tahapan selanjutnya adalah merencanakan bahan ajar yang sesuai dengan kebutuhan guru dan peserta didik, yaitu bahan ajar tematik berbasis kearifan lokal Jawa Tengah. Bahan ajar tematik yang dikembangkan diharapkan memudahkan guru dalam mengajarkan kearifan lokal yang ada di lingkungan sekitar peserta didik, yaitu kearifan lokal Jawa Tengah. Selain itu juga dapat menarik kemauan belajar peserta didik sehingga mereka antusias dalam mengikuti pembelajaran tematik maupun untuk belajar mandiri. Bahan ajar yang dikembangkan juga diharapkan mampu mengenalkan kearifan lokal Jawa Tengah sehingga peserta didik mengetahui kearifan lokal yang ada di daerahnya dan mampu menjaga kearifan lokal tersebut agar tidak punah tergerus jaman.

\section{SIMPULAN}

Berdasarkan hasil studi eksplorasi di lapangan dapat disimpulkan bahwa (1) pada umumnya pengetahuan guru tentang pembelajaran tematik berbasis kearifan lokal masih kurang, guru belum sepenuhnya melaksanakan dan menerapkan kearifan lokal dalam proses pembelajaran tematik. Selain itu, peserta didik menyatakan bahwa bahan ajar yang digunakan selama ini kurang menarik dan mereka merasa kesulitan dalam memperoleh informasi melalui bahan ajar yang digunakan selama ini. (2) Penerapan pembelajaran tematik berbasis kearifan lokal belum sepenuhnya dilaksanakan oleh guru. Hal ini dapat dilihat dari bahan ajar tematik yang digunakan terfokus pada bahan ajar dari pemerintah dan penerbit tertentu yang belum banyak mengajarkan adanya kearifan lokal masing-masing daerah khususnya Jawa Tengah. Hasil yang ditunjukkan pada kegiatan studi eksplorasi tersebut maka kiranya perlu dilakukan beberapa hal sebagai berikut. (1) Perlu adanya peningkatan pemahaman guru mengenai pembelajaran tematik berbasis kearifan lokal khususnya Jawa Tengah melalui kegiatan pelatihan dan pendampingan guru. (2) Perlu penyediaan bahan ajar yang dapat menarik perhatian peserta didik sekaligus dapat menambah informasi tentang kearifan lokal dalam pembelajaran tematik, yaitu berupa bahan ajar tematik berbasis kearifan lokal.

\section{DAFTAR PUSTAKA}

Gogoi, Sampreety. (2015). Importance's of Teaching Learning Materials for Young Children. International Journal of Current Research Vol. 7, Issue, 09, pp.2026920273, September, 2015. Diakses dari http://www.journalcra.com/sites /default/files/10372.pdf pada tanggal 19 Mei 2018

Fogarty and Jacobs. (2009). How to Integrated the Curricula. United States of America. Library of Congress Cataloging in Publication Data

Mungmachon. (2012). Knowledge and Local Wisdom: Community Treasure. International Journal of Humanities and Social Science Vol 2 No 13. Diakses dari http://www.ijhssnet.com/journals/Vol 2 No 13 July 2012/ 18.pdf pada tanggal 19 Mei 2018

Northcote, M., Kilgour, P., Reynaud, D., \& Fitzsimmons, P. (2014). Engaging in Deep Cultural Learning through the Intersection of Multiple Contexts. Australian Journal of Teacher Education. 39 (10), 47-63

Nurlaela, Samani, Asto dan Wibawa. (2018). The effect of thematic learning model. Learning style, and reading ability on the student's learning outcomes. $\underline{I O P}$ Conference Series: Materials Science and Engineering, Volume 296, conference 1 diakses dari http://iopscience.iop.org/article/10.1088/1757899X/296/1/012039/ pdf pada tanggal 19 Mei 2018

Opera, Jacinta and Oguzor, Nkasiobi S. (2011). Instructional Technologies and School Curriculum in Nigeria: Innovations and Challenges. Perspectives of Innovations, Economics \& Business, Volume 7, Issue 1, 2011 
Prastowo, A. (2012). Panduan Kreatif Membuat Bahan Ajar Inovatif. Yogyakarta: DIVA Press.

Sumarmi dan Amirudin. (2014). Pengelolaan Lingkungan Berbasis Kearifan Lokal. Malang: Aditya Median Publising

Tinja, Towaf, Hariyono. (2017). Pengembangan Bahan Ajar Tematik Berbasis Kearifan Lokal sebagai Upaya Melestarikan Nilai Budaya pada Siswa Sekolah Dasar. Jurnal Pendidikan: Teori, penelitian, dan Pengembangan Vol 2 No 9. Diakses dari journal.um.ac.id/index.php/jptpp/article/ view/9990 pada tanggal 19 Mei 2018

Utari, Degeng, Akbar. (2016). Pembelajaran Tematik Berbasis Kearifan Lokal di Sekolah Dasar dalam Menghadapi Masyarakat Ekonomi Asean (MEA). Jurnal Teori dan Praksis Pembelajaran. Diakses dari journal.um.ac.id/index.php/jtppips/article/view/5861 pada tanggal 19 Mei 2018 